\title{
MENINGKATKAN AKTIFITAS DAN KEMAMPUAN KOGNITIF MATEMATIKA SISWA KELAS VIII.2 PADA MATERI RELASI DAN FUNGSI
}

\author{
Hasdelyati \\ SMPN 18 Kota Bengkulu \\ hasdelyati86@gmail.com
}

\begin{abstract}
Abstrak
Penelitian ini bertujuan untuk meningkatkan aktifitas dan kemampuan kognitif melalui hasil belajar siswa dengan menerapkan strategi pembelajaran kooperatif Student Team Achievement Divisions. Penelitian ini adalah penelitian Tindakan Kelas (PTK) dengan teknik pengumpulan data melalui lembar observasi aktifitas dan tes siklus siswa. Subjek penelitian ini adalah siswa kelas VIII.2 SMP Negeri 18 Kota Bengkulu Semester Ganjil Tahun Ajaran 2019/2020 berjumlah 25 siswa. Hasil penelitian menunjukkan bahwa penerapan strategi pembelajaran Pembelajaran kooperatif Student Team Achievement Divisions dapat meningkatkan aktifitas dan kemampuan kognitif siswa. Peningkatan hasil belajar ranah kognitif siswa dapat dilihat dari nilai rata-rata hasil belajar siswa dari pra siklus, siklus I dan siklus II secara berturut-turut adalah 69,5; 73,32; dan 83,68 serta ketuntasan belajar klasikal pra siklus I, siklus II dan siklus III secara berturut-turut adalah $40 \% ; 64 \%$; dan $80 \%$. Peningkatan aktifitas belajar siswa dapat di lihat dari nilai hasil observasi aktifitas belajar matematika siswa siklus I, dan siklus II, secara berturut-turut adalah 22,34 (kriteria cukup) dan 25,34 (kriteria aktif).
\end{abstract}

Kata kunci: Aktifitas, Hasil Belajar, Pembelajaran kooperatif Student Team Achievement Divisions

\begin{abstract}
This study aims to improve cognitive activities and abilities through student learning outcomes by applying the learning strategy of Student Team Achievement DivisionsThis study is a Classroom Action Research (CAR) with data collection techniques through activity observation sheets and student cycle tests. The subject of this research were student of class VIII 7 at SMP Negeri 18 Kota Bengkulu in academic year 2018/2019 with total number of 32 students.The results of the study showed that the implementation of cooperative learning strategies for Student Team Achievement Divisionscan increase student activity and cognitive abilities. Increasing students' cognitive learning outcomescan be seen from the average value of student learning outcomes pra cycle, cycle I and cycle II respectively is 69,5; 75,32; and 83,68 and classical learning completeness pra cycle, cycle I and cycle II respectively are 40\%; 64\%; and 80\%.Increased learning activities of students can be seen from the value of observations of students' mathematics learning activities in cycle I, and cycle II, 22.34 (sufficient) and 25.34 (active).
\end{abstract}

Keywords: Activity, Learning Outcomes, Student Team Achievement Divisions cooperative learning

\section{PENDAHULUAN}

Pembelajaran merupakan proses interaksi antara peserta didik dan pengajar untuk mencapai suatu tujuan pendidikan. Slameto (2010: 2) menyatakan bahwa belajar ialah suatu proses usaha yang dilakukan seseorang untuk memperoleh suatu perubahan tingkah laku yang baru secara keseluruhan,sebagai hasil pengalamannya sendiri dalam interaksi dengan lingkungannya. Proses belajar yang baik dapat membantu peserta didik dalam memahami materi pembelajaran dengan mudah. Menurut Djamarah dan Zain (2006:146) pembelajaran yang kondusif merupakan kondisi pembelajaran yang menyenangkan bagi anak didik sehingga anak didik giat belajar, banyak melakukan aktifitas dan dapat mengoptimalkan hasil belajar baik dari aspek kognitif, afektif, 
maupun psikomotor.

Proses pembelajaran merupakan salah satu elemen dari standar proses yang mengalami perubahan guna pencapaian keberhasilan pembelajaran dan pembentukan kompetensi siswa, khususnya pada Kurikulum 2013. Pada kurikulum 2013 terdapat berbagai mata pelajaran, salah satunya adalah pelajaran matematika. Matematika berasal dari bahasa latin Manthanein atau mathema yang berarti "belajar atau hal yang dipelajari." Sedang dalam bahasa Belanda disebut Wiskunde atau "ilmu pasti" (Shadiq, 2014:5). Matematika merupakan sebuah ilmu pasti yang dapat meningkatkan daya pikir. Menurut De Lange dalam Shadiq (2014:9) bahwa pentingnya pembelajaran matematika dalam menata kemampuan berpikir para siswa, bernalar, memecahkan masalah, berkomunikasi, mengaitkan materi matematika dengan keadaan sesungguhnya, serta mampu menggunakan dan memanfaatkan teknologi. Salah satu materi yang ada pada pembelajaran matematika adalah materi relasi dan fungsi. Kurangnya pemahaman peserta didik terhadap konsep salah satunya pelajaran relasi dan fungsi merupakan salah satu masalah yang sering terjadi, termasuk pada peserta didik kelas VIII.2 SMP Negeri 18 Kota Bengkulu yang mana peserta didik mengalami kesulitan saat menjawab soal dari materi relasi dan fungsi. Kesulitan tersebut karena masih rendahnya minat belajar dan sikap pasif peserta didik selama proses pembelajaran, peserta didik tidak dapat bekerja sama dengan teman sekelasnya, dan sebagainya.

Masalah-masalah tersebut dapat diatasi dengan memberikan usaha perbaikan dalam pembelajaran salah satunya dengan menerapkan sebuah model pengajaran matematika yang dapat merangsang siswa untuk belajar secara aktif dalam proses belajar mengajar dari metode dan model pembelajaran yang ada. Salah satu alternatif yang dapat dilakukan untuk meningkatkan aktifitas siswa dan kemampuan kognitif dalam mempelajari matematika adalah dengan menggunakan model kooperatif tipe Student Team Achievement Divisions yang dikembangkan oleh Robert Slavin dan teman-teman di
Universitas Hopkins. Menurut Huda (2012:20) Student Team Achievement Division merupakan salah satu strategi pembelajaran kooperatif yang didalamnya terdapat beberapa kelompok kecil siswa dengan level kemampuan akademik yang berbeda-beda saling berkerja sama untuk menyelesaikan tujuan pembelajaran.

Sesuai dengan tujuan penelitian, variabel yang akan diukur pada penelitian ini adalah aktifitas belajar dan kemampuan kognitif matematika peserta didik. Aktifitas belajar merupakan keterlibatan siswa dalam bentuk sikap, pikiran, perhatian dalam kegiatan belajar guna menunjang keberhasilan proses belajar mengajar dan memperoleh manfaat dari kegiatan tersebut. Salah satu ranah pada klasifikasi tujuan pendidikan adalah ranah kognitif. Menurut Bloom, segala upaya yang menyangkut aktifitas otak adalah termasuk dalam ranah kognitif. Segala aktifitas yang berhubungan dengan kemampuan berpikir, seperti menghafal, memahami, mengaplikasi, menganalisis, mensintesis, dan kemampuan mengevaluasi termasuk ke dalam ranah kognitif.

Penelitian ini dilakukan dengan tujuan untuk mengetahui penerapan model pembelajaran kooperatif Student Team Achievement Divisions dapat meningkatkan kemampuan kognitif peserta didik di kelas VIII.2 SMP Negeri 18 Kota Bengkulu pada materi relasi dan fungsi, serta untuk mengetahui aktifitas dan kemampuan kognitif peserta didik selama kegiatan pembelajaran melalui model pembelajaran kooperatif Student Team Achievement Divisions di kelas VIII.2 SMP Negeri 18 Kota Bengkulu pada materi relasi dan fungsi.

\section{METODE}

Jenis penelitian yang digunakan pada penelitian ini adalah Penelitian Tindakan Kelas (PTK). Menurut Sanjaya (2011 : 26) Penelitian Tindakan Kelas adalah proses pengkajian masalah pembelajaran didalam kelas melalui refleksi diri dan upaya untuk memecahkannya dengan cara melakukan berbagai tindakan yang terencana dalam situasi nyata serta menganalisis setiap 
pengaruh dari tindakan tersebut. Subjek penelitian ini adalah siswa kelas VIII.2 SMP Negeri 18 Kota Bengkulu tahun ajaran 2019/2020, dengan penelitian yang dilaksanakan dengan dua siklus dengan tahapan perencanaan, pelaksanaan, pengamatan, dan refleksi. Instrumen yang digunakan pada penelitian ini adalah lembar observasi aktifitas belajar dan lembar tes belajar. Dalam penelitian ini, peneliti menggunakan teknik analisis data secara kuantitatif dan kualitatif. Data kuantitatif dianalisis dengan stastistik deskriptif untuk menemukan persentase dan nilai rata-rata dengan rumus sebagai berikut:

a. Persentase aktifitas belajar siswa diperoleh denganrumus:

Kisaran skor untuk tiap kriteria
skor tertinggi - skor terendah

(Modifikasi Sudijono, 2003:49-50)

Kriteria penilaian lembar observasi aktifitas siswa dapat dilihat melalui tabel berikut.

Tabel 1. Kriteria Penilaian untuk Lembar Observasi Aktifitas Siswa

\begin{tabular}{|c|c|c|}
\hline Kriteria Penilaian & Notasi & Skor \\
\hline Kurang & K & 1 \\
\hline Cukup & C & 2 \\
\hline Baik & B & 3 \\
\hline
\end{tabular}

Keterangan :

Skor Tertinggi $=$ jumlah butir observasi $\times$ skor tertinggi tiap butir observasi

Skor Terendah $=$ jumlah butir observasi $\times$ skor terendah tiap butir observasi

Kriteria yang digunakan adalah Kurang

(K), Cukup (C), dan Baik (B)

Kisaran skor penilaian untuk lembar observasi aktifitas siswa adalah sebagai berikut.

Tabel 2. Kriteria Skor Pengamatan untuk Lembar Observasi Aktifitas Siswa

\begin{tabular}{|c|c|}
\hline Kriteria Penilaian & Kisaran Skor \\
\hline Kurang aktif & $10 \leq \mathrm{x} \leq 16$ \\
\hline Cukup aktif & $16<\mathrm{x} \leq 23$ \\
\hline Aktif & $23<\mathrm{x} \leq 30$ \\
\hline
\end{tabular}

(Modifikasi Sudijono, 2003:49-50)

Keterangan :

$\mathrm{x}=$ Rata-rata skor hasil observasi

b. Kemampuan kognitif belajar siswa diperoleh dengan rumus

$$
N A=\frac{\text { Nilai skor benar }}{\text { Skor Maksimum }} \times 100
$$

Penelitian ini diharapkan dapat memenuhi indikator ketercapaian yang telah ditentukan berdasarkan:

1. Hasil pengamatan melalui lembar observasi aktifitas belajar siswa pada akhir siklus menunjukkan kriteria "Baik" dengan skor 75\%-85\% atau lebih.

2. Hasil kemampuan kognitif siswa 
pada belajar matematika melalui lembar tes pada akhir siklus menunjukkan rata-rata nilai 75- 100 sesuai standar KKM pada sekolahtersebut.

\section{HASIL PENELITIAN DAN PEMBAHASAN}

Penelitian Tindakan Kelas dengan menerapkan model pembelajaran
Kooperatif Tipe Student Team Achievement Divisions untuk meningkatkan aktifitas dan kemampuan kognitif peserta didik dikelas VIII.2 SMP Negeri 18 Kota Bengkulu dilaksanakan dalam 2 siklus. Data aktifitas belajar peserta didik yang diperoleh setiap siklusnya dapat dilihat pada Tabel 1 di bawah ini.

Tabel 3. Rata-rata Hasil Pengamatan Aktifitas Siswa Setiap Siklusnya

\begin{tabular}{|c|c|c|}
\hline & Siklus 1 & Siklus 2 \\
\hline Pengamat 1 & 22 & 25 \\
\hline Pengamat 2 & 22,67 & 25,67 \\
\hline Rata-rata & 22,34 & 25,34 \\
\hline Kategori & Cukup Aktif & Aktif \\
\hline
\end{tabular}

Pada siklus I dan II, keaktifan peserta didik pada model pembelajaran Kooperatif Tipe Student Team Achievement Divisions dikategorikan cukup aktif dengan rata-rata 22,34 pada siklus I dan 25,34 pada siklus II. Pada siklus I, siswa cukup aktif dalam memperhatikan penjelasan dari guru, namun ada beberapa siswa masih belum serius dalam melaksanakan proses pembelajaran yang diterapkan guru, misalnya masih melakukan aktifitas lain selain dari kegiatan belajar. Pertemuan dari siklus II, siswa mengikuti pembelajaran dengan baik, semangat mengerjakan soal didalam LKS semakin meningkat, lalu ketika mengalami kesulitan dalam pembelajaran siswa berani bertanya dengan guru apa yang dianggap sulit bagi mereka. Aktifitas siswa diluar kegiatan belajar mengajar sudah berkurang.

Aktifitas belajar merupakan keterlibatan siswa dalam bentuk sikap, pikiran, perhatian dalam kegiatan belajar guna menunjang keberhasilan proses belajar mengajar dan memperoleh manfaat dari kegiatan tersebut. Keberhasilan proses belajar dapat dilihat melalui hasil belajar Siklus I yaitu dari nilai latihan dan tes akhir Siklus I. Hasil belajar dari nilai latihan dan tes akhir, peserta didik belum mendapatkan poin yang maksimal. Berikut ini contoh Penyelesaian masalah LKS pada pertemuan 1 siswa yang belum benar.

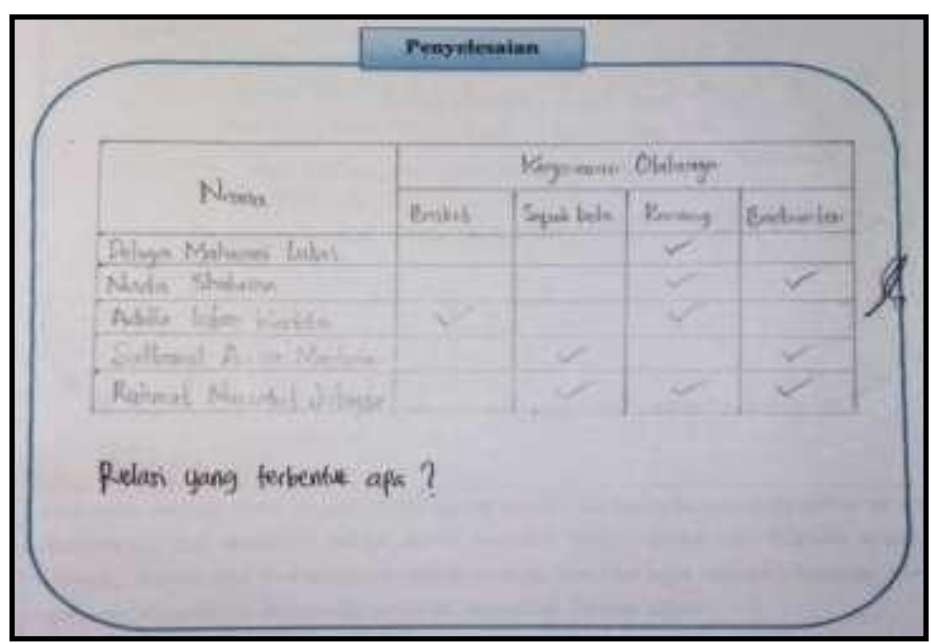


Gambar 1. Penyelesaian Masalah LKS pada Pertemuan 1 Siswa yang Belum Benar

Pada gambar 1 menunjukkan bahwa siswa tersebut belum memahami relasi apa yang terbentuk antara himpunan anak dengan himpunan cabang olahraga yang diberikan dengan benar. Siswa hanya menuliskan himpunan anak dan mencentang kegemaran olahraga pada tabel, tidak menuliskan apa relasi yang terbentuk antara kedua himpunan. Sedangkan gambar untuk pemahaman masalah yang benar adalah sebagai berikut:

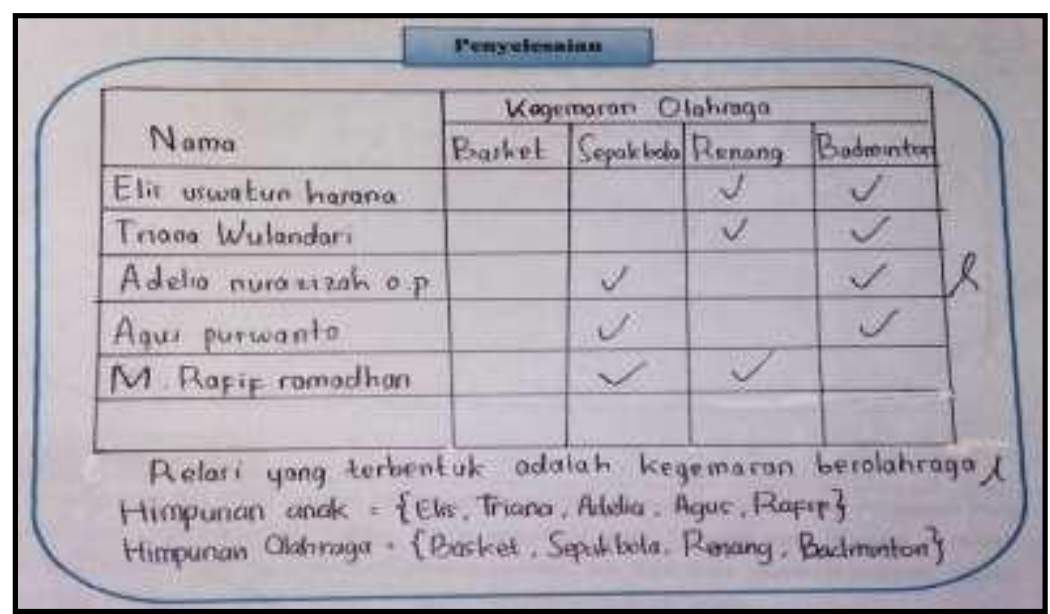

Gambar 2. Penyelesaian Masalah LKS pada Pertemuan 1 Siswa yang Benar

Pada gambar 2 siswa mampu memahami masalah dengan menuliskan nama anggota kelompok dan membuatnya menjadi himpunan anak sedangkan nama-nama cabang olahraga menjadi himpunan olahraga. Siswa sudah memahami relasi apa yang terbentuk antara himpunan anak dengan himpunan cabang olahraga. Peningkatan nilai rata-rata siswa dapat dilihat pada gambar grafik berikut ini.

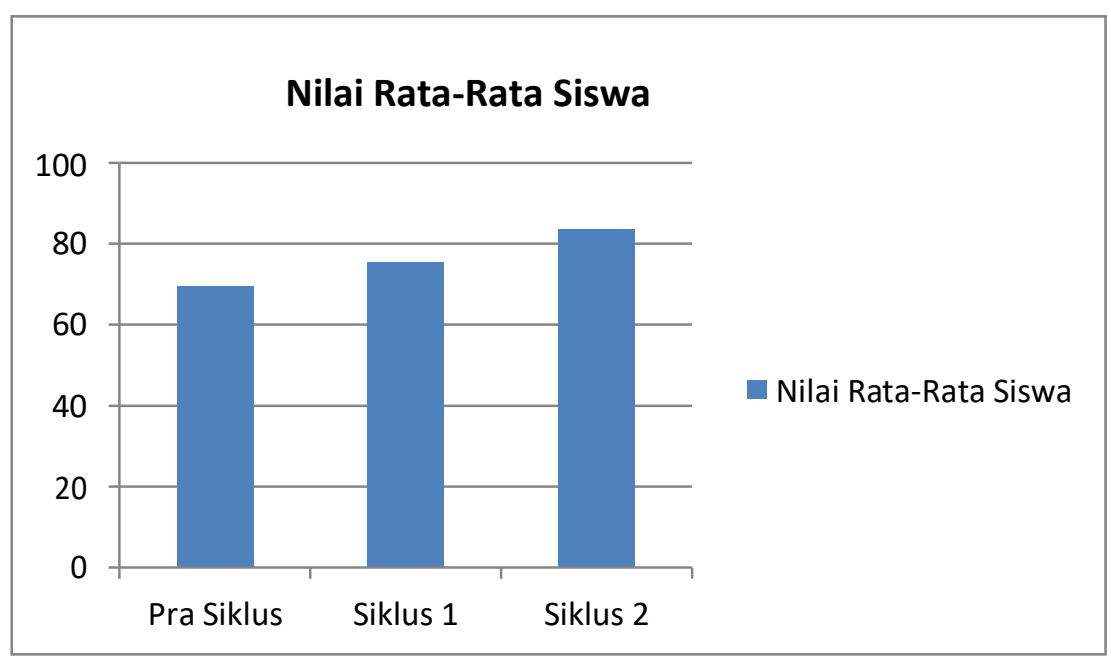

Gambar 3. Grafik Nilai Rata-rata Siswa Setiap Siklus

Nilai rata-rata siswa selalu mengalami peningkatan pada setiap siklusnya Ratarata nilai akhir pada siklus II telah memenuhi indikator keberhasilan. Peningkatan hasil belajar untuk ranah kognitif siswa secara berturut-turut dari 
siklus ke I sampai siklus ke II,yaitu nilai rata-rata siswa pada siklus ke I sebesar 73,32 meningkat disiklus II sebesar83,68.
Sedangkan peningkatan ketuntasan belajar secara klasikal dapat dilihat pada grafik berikut:

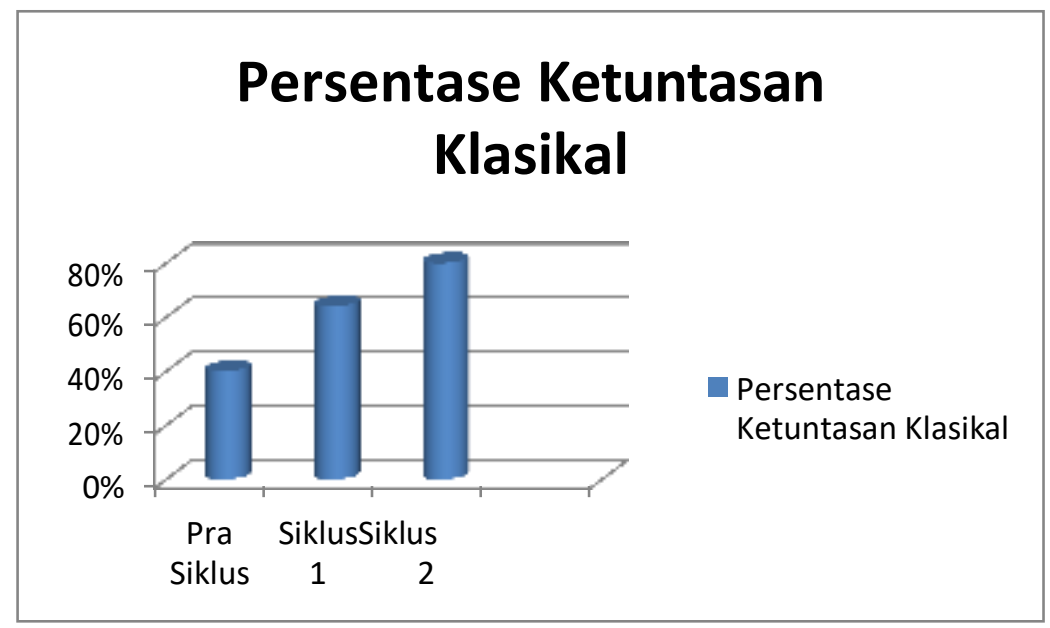

Gambar 4. Grafik Peningkatan Ketuntasan Hasil Belajar Klasikal Siswa

Grafik di atas memperlihatkan bahwa ketuntasan belajar klasikal peserta didik selalu mengalami peningkatan pada setiap siklusnya. Peningkatan belajar tersebut meningkat dengan persentase yang cukup besar. Berdasarkan hasil tersebut, penepanan Student Team Achievement Division dapat digunakan untuk meningkatkan aktifitas dan hasil belajar siswa. Adanya tahap kerja kelompok memberikan kesempatan kepada siswa untuk berinteraksi dengan siswa lain dan mendiskusikan apa yang belum mereka pahami dengan siswa yang lain.

\section{SIMPULAN}

Penerapan model pembelajaran kooperatif Student Team Achievement Divisions di kelas VIII.2 SMPN 18 Kota Bengkulu dapat meningkatkan aktifitas dan kemampuan kognitif belajar siswa dengan cara membantu siswa dalam memahami masalah yang terdapat di dalam LKS serta membimbing dan mengarahkan siswa dalam penyelidikan dari permasalahan yangdiberikan.

Penerapan model pembelajaran kooperatif Student Team Achievement Divisions dapat mempengaruhi aktifitas dan kemampuan kognitif dalam hasil belajar siswa kelas VIII.2 SMPN 18 Kota
Bengkulu. Peningkatan aktifitas siswa terlihat dari skor aktifitas siswa pada siklus I dengan rata-rata skor 22,34 masih tergolong cukup aktif, siklus II meningkat kriteria aktif dengan skor 25,34. Serta peningkatan hasil belajar siswa dapat dilihat dari nilai rata-rata dan ketuntasan belajar siswa pada setiap siklus. Pada siklus I, nilai rata-rata hasil belajar siswa 73,32 dengan persentase ketuntasan belajar klasikal 64\%. Pada siklus II, nilai rata-rata hasil belajar siswa menjadi 83,68 dengan persentase ketuntasan belajar klasikal sebesar $80 \%$.

\section{REFERENSI}

Djamarah, S.B. \& Zain. (2006). Strategi Belajar Mengajar. Jakarta: Rineka Cipta. Huda, Miftahul. (2012). Cooperative Learning. Yogyakarta: Pustaka Belajar.

Sanjaya. (2011). Strategi Pembelajaran Berorientasi Standar Proses Pendidikan. Jakarta: Bumi Aksara

Shadiq, F. (2014). Pembelajaran Matematika. Yogyakarta: Graha Ilmu.

Slameto. (2010). Belajar dan Faktor-faktor yang Mempengaruhinya. Jakarta: Rineka Cipta.

Sudijono. (2003). Pengantar Statistik Pendidikan. Jakarta: Raja Grapindo Persada. 